Article

\title{
A Multivariate VAR Model for Evaluating Sustainable Finance and Natural Resource Curse in West Africa: Evidence from Nigeria and Ghana
}

\author{
Olatunji Abdul Shobande ${ }^{1, *}$ and Joseph Onuche Enemona ${ }^{2}$ \\ 1 Department of Economics, Business School, University of Aberdeen, Aberdeen AB243RX, UK \\ 2 Department of Economics, Babcock University, Ilishan-Remo 121103, Nigeria; joseph0116@pg.babcock.edu.ng \\ * Correspondence: o.shobande.19@abdn.ac.uk; Tel.: +44-7432-818-872
}

Citation: Shobande, O.A.; Enemona, J.O. A Multivariate VAR Model for Evaluating Sustainable Finance and Natural Resource Curse in West Africa: Evidence from Nigeria and Ghana. Sustainability 2021, 13, 2847. https://doi.org/10.3390/su13052847

Academic Editor: Sebastian Kot

Received: 2 February 2021

Accepted: 1 March 2021

Published: 5 March 2021

Publisher's Note: MDPI stays neutral with regard to jurisdictional claims in published maps and institutional affiliations.

Copyright: (C) 2021 by the authors. Licensee MDPI, Basel, Switzerland. This article is an open access article distributed under the terms and conditions of the Creative Commons Attribution (CC BY) license (https:/ / creativecommons.org/licenses/by/ $4.0 /)$.

\begin{abstract}
The financial sector plays a critical role in society by mediating resources and assets within the economy between surplus and deficit units. Therefore, they have a great responsibility for the sustainability and prosperity of natural endowments. This study aimed to determine whether sustainable finance matters for the natural resource curse in Nigeria and Ghana. The empirical evidence is based on the Bayer and Hanck combined cointegration tests and Vector Autoregressive/Vector Error Correction Granger causality tests. The study highlights the importance of sustainable financing in natural resources management. Our findings also confirmed the existence of the financial resource curse in Nigeria and Ghana. Likewise, the medium through which sustainable finance affects the natural resource curse has been identified as the human development index (economic welfare). This current study has critical policy implications that suggest the need to establish a vibrant, sustainable financing strategy to assist domestic private investors with a strong interest in natural resource exploration and development, taking into account macroeconomic sustainability. Additionally, it also important to build a strong financial market which allows for policies designed to promote natural resource management.
\end{abstract}

Keywords: sustainable financing; natural resources curse; Bayer and Hanck combined cointegration; tests; Granger causality; West Africa

\section{Introduction}

In the context of Ghana and Nigeria, this study examined the role of financial access in the natural resource endowments and established whether financing leans toward the credibility of the resource curse hypothesis. Natural resources have the potential to stimulate economic growth and impede economic development. This means that natural resources can be both a blessing and a curse [1-5]. Similarly, it is easy to theorise how economic growth has been delayed or prolonged in natural resource-rich countries using the well-known resource curse hypothesis, but the resource curse theory must ultimately bows to real-world evidence [6-8]. For example, many have found that dependency on natural resources has a major impact on prolonged growth and socioeconomic development [9-12]. However, some studies have refuted the existence of a resource curse and argued that the extent to which the abundance of natural resource generates developmental outcomes depends largely on many factors [13-15]. While recent studies have identified natural resources as an instrument of growth, the question of sustainable financing required to maintain resource endowments has remained unsettled. For example, Benigno and Fornaro [16] argue that sustainable financing can effectively promote natural resources. On the contrary, recent studies by Adetutu et al. [17] have advanced the idea that bank productivity declines during oil booms. Fijorek et al. [18] stepped up the debate, championing the claim that financial crises have a major impact on the mining sector. However, it is unclear whether financial access can help foster the efficient management of natural resources. 
Instead of ignoring the role of financial development in natural resource utilisation, a better approach is to consider what Adetutu et al. [17] and Benigno and Fornaro [16] say about the theory of financial and the resource curse, and how it can go wrong and where it can be beneficial for nations abundant with resources.

Investigating the financial resources curse for Nigeria and Ghana is motivated by two reasons. Firstly, this study seeks to determine whether financial access can be a process that can transition natural resources from curses to blessings among resource-rich countries. For example, Nigeria is blessed with abundant resources and remains a key player in the oil and gas sector. The oil and gas industry accounts for approximately $75 \%$ of government revenue and $88 \%$ of foreign exchange earnings in Nigeria [19-22]. Among other factors, the capacity for Nigeria to discover more natural resources and maintain existing ones may be significantly reduced due to insufficient funding $[9,19,23]$. As opposed to the former, Ghana is blessed with abundant natural resources ranging from gold production to oil and gas $[24,25]$. Currently, Ghana produces over 158 tonnes of gold, and the mining sector contributes to over $90 \%$ of total mineral exports [26]. Similarly, Ghana has abundant natural gas reserves that have remained untapped due to poor access to finance [24,27]. Thus, it is unclear whether access to finance can help these two countries better reposition their resources. Secondly, studies have shown that access to finance is important to escape the vicious cycle of poverty for countries rich in resources and to address their socioeconomic woes $[16,28,29]$. For example, oil exploration has turned Nigeria's agricultural society into an oil-producing oil nation, but not without infrastructural deficits or slow socioeconomic development. The same can be said of Ghana, with ample gold and natural resource reserves, but with a low growth trajectory.

In extant literature, financial access can affect effective natural resource management in several ways. Firstly, many natural resources remain untapped owing to a lack of financing to explore them. For instance, because of poor access to finance, many parts of Nigeria have abundant resources that are still undiscovered. Similarly, Ghana has oil and an abundance of natural resources that have remained untapped until recently. Second, the lack of support for resource exploitation after discovery renders the resource a curse rather than a blessing. Third, some studies have blamed financial institutions for their failure to help finance natural resources [8,12,30-32]. In particular, Wang et al. [12] have argued that financial intermediaries should be blamed for their failure to mobilise resources towards effective natural resource management in developing countries.

This study contributes to the existing literature in many ways. (1) It investigates whether sustainable finance can promote natural resource management within Nigeria and Ghana, (2) by considering various confounders, the study identified the mechanism through which sustainable finance can affect natural resource curse, and (3) the study makes an important methodological contribution by employing the Bayer and Hanck [33] and Vector Autoregressive (VAR)/Vector Error Correction (VEC) Granger causality tests to dissect the short- and long-run dynamics among the factors and makes inference with respect to the causation link. The empirical findings show that cointegration exists among the variables, whereas convergence to long-term means is greater in Nigeria but slower in Ghana. Likewise, the finding shows that financial access unidirectionally Granger causes natural resources in Ghana, whereas bidirectional Granger causality was observed in Nigeria.

The remainder of this paper is organised as follows: Section 2 presents the literature review and the hypotheses tested. Section 3 describes the data and research methodology. Section 4 presents the empirical results, and Section 5 concludes with suggestions for further studies.

\section{Literature Review}

\subsection{Conceptual Framework}

Generally, finance is defined as risk and return, while sustainable finance manages cost and risk associated with natural resources, environment, social, and improving wellbe- 
ing [34-36]. The concepts of sustainable financing consider how the investing and lending can be used by the financial sector to manage natural resources and improve the environment and social wellbeing [37-43]. The financial sector can help mobilised funds to improve sustainable natural resources, which can generate combinations of return to improve human welfare. Sustainable finance can help in the strategic allocating of resources toward natural resource discovery, production, and utilisation. Sustainable finance will help provide a long-term solution to environmental uncertainty and act as a catalyst for the realisation of the sustainable development goal [36,44-52]. Sustainable financing leads to investments in education, health, and other factors that can promote wellbeing.

The goal of sustainable finance is to increase finance's contribution to sustainable and inclusive development [53]. In particular, the goal is to encourage economic development while reducing environmental pressures, addressing greenhouse gas emissions and pollution control, and improving the quality of the use of natural resources [54-59]. Busch et al. [60] explores the role of financial markets for sustainable development. The author assessed whether financial markets have promoted the Environment, Social and Governance (ESG) framework and concludes that there seems to be no real shift toward sustainability in the present practice of financial institutions. Zhu et al. [61] examines the link between financial inclusion and sustainability and reported that financial inclusion can provide a balance between sustainability and economic growth.

Using a meta-analysis approach, Akomea-Frimpong et al. [49] systematically evaluate 46 theoretical papers on green finance in the banking sector and observed that the financial sector approach toward sustainable financing includes green loan/bonds, green securities, carbon financing, and climate financing. Migliorelli [42] surveyed the sustainable finance landscape in its existing framework and contends that rebranding financial flows and cost of capital spread is crucial for implementing policy tailored toward sustainability. Focusing on Asian countries, Tolliver et al. [62] examined sustainable financing within the green innovation contest and argued that information disclosure is crucial for implementing sustainable growth paradigms. Flammer [63] examined corporate green bonds towards climate financing and reported that credible commitment and effective implementation of green bonds could promote sustainability.

Focusing on Australia, Galbreath [64] provides evidence of sustainable finance within the ESG framework using the dataset source from the Australian Securities Exchange for 300 firms for the period 2002-2009. The author concludes that the idea of sustainable finance is integrated into higher impact industries, whereas sustainable finance is yet to be implemented in medium and low industries in Australia. Using a country level measure, Abdul Razak et al. [65] examines the effects of credit default swap spreads in sustainability for a sample of 2094 global non-financial firms for the period 2013-2016 and reported that risk reduction affects firm performance during the period examined. Cappasso et al. [66] investigates the relationship between exposure to climate change and credit risk and reported that climate risk reduces credit worthiness of loans and bonds issued in financial markets. Baur and Hann [67] show that environmental degradation is associated with poor credit rating. Chava [68] indicates that environmental threat has implications for the high cost of bank loans. Using a comparative descriptive analysis, Escrig-Olmedo et al. [57] evaluate the sustainable finance within the environment, social, and governance (ESG) perspectives. The authors used rating and information provided by agencies in the financial market for the period 2008 to 2018 and reported that there is a missing link between ESG and sustainability.

\subsection{Related Studies}

Questions regarding the existence of a resource curse have become central to emerging empirical research. The outcomes of these studies have affected policymaking and stakeholder involvement. However, a strand of literature focusing on whether financial access can play a part in efficient natural resource utilisation has remained inconsistent and controversial. Thus, Redmond and Nasir [8] examined the impact of natural resource 
abundance, international trade, and financial development for a balanced panel dataset of 30 countries between 1990 and 2016 using fixed effect, random effect, fully modified generalised least squares, and panel dynamic least squares. They discovered that natural resources have a significant positive impact on growth. Using rich monthly microdata, Adetutu et al. [17] examined the effect of commodity booms on bank productivity within the resource-endowed economies and reported that a decline in bank productivity is related to oil booms.

Using the Bootstrap Granger full sample and rolling window estimation for subsamples, Wang et al. [12] explored a time-varying relationship between financial development and the natural resources curse in Pakistan from 1971 Q1 to 2017 Q4. They reported the bidirectional Granger causality between financial development and natural resources. Asif et al. [31] examined the interaction between financial development and natural resource curse using bound testing, decomposition analysis, and impulse response function and reported that natural resources decrease market capitalisation to validate financial resource curse. Similarly, Faisal et al. [69] investigated the asymmetric relationship between financial deepening and natural resources using quarterly data from 1990 Q1 to 2016 Q4. Their study employed five structural break tests, Maki cointegration, and nonlinear autoregressive distributed lag cointegration, and it discovered an asymmetric relationship among the variables.

Using the Arellano Bond generalised method of moment, Dwumfour and NtowGyamfi [14] scrutinised the relationship between natural resources and financial development for 38 African countries from 2000 to 2012. They reported that a resource curse was seen when a Z-score was used to proxy financial development in sub-Saharan Africa. Conversely, Bhattacharyya and Holder [70] examined whether a natural resource can be an impediment to financial development and discovered a negative relationship among the variables. Kurronen [71] investigated financial sector characteristics in resource-dependent economies using the dataset for 128 countries from 1996 to 2009 and discovered that financing was needed to spur growth among the resource-dependent economies examined. Furthermore, Benigno and Fornaro [16] queried Spain's financial resource curse and argued that capital control could promote Spain's economic welfare during the period examined. Benigno et al. [72] examined the global financial resource curse and reported that capital flow from developing countries into the United States could generate a global growth slowdown.

Using a meta-analysis, Zhang and Brouwer [15] investigate the resources curse hypothesis in 44 provinces in China for 2005-2017 and reported a resource curse for China. Canh and Thong [73] investigate the link between natural resources rent in a global sample panel of 86 countries over the period 2002 to 2017 and reported that financial development positively influences natural resources through the financial market. Shahbaz et al. [10] show the existence of long run cointegration between financial development and natural resources in the United States. In contrast, Kahn et al. [74] observe a negative influence of financial development on Pakistan's natural resources. Zaidi et al. [30] investigate natural resource abundance and financial development for a panel of thirty countries using continuously updated modified ordinary least squares and discovered a positive influence of natural resources on financial development. Guan et al. [75] investigated natural resources and financial development for China between 1971 to 2017 using the Bayer and Hanck [33] cointegration and autoregressive distributed lag model and discovered a negative impact of a natural resource on financial development. Yildrim et al. [76] examined natural resources revenue and financial development in 16 developing countries between 1994 and 2017 and reported that an increase in oil revenue positively influences financial development. Gokmenoglu and Rustmav [77] examined the role of World Bank lending in natural resource curse in Kazakhstan, Azerbaijan, Russia, and Turkmenistan countries and reported that natural resources positively promote financial development.

Using provincial panel data from China, Yuxiang and Chen [78] examined the link between financial development and the mining sector and discovered a significant positive 
relationship between financial development and mineral resources. Likewise, Fijorek et al. [18] examined the link between the financial and mining sector in eight countries (Australia, Canada, China, India, Russia, South Africa, the United Kingdom, and the United States) using the contagion symmetric and asymmetric Vector Autoregressive approach for the period 2008-2019. They reported that the strong impact of financial crises also affected the mining sector.

The empirical review shows a considerable level of divergence among prominent studies on the link between financial development and natural resources. While some studies have argued that natural resources can serve as an impediment to the financial sector (see $[17,18])$, others appear to favour financial development to upturn the resource curse to a blessing (see $[14,78]$ ), whereas few studies find both positive and negative relationships between financial development and natural resources [12,71]. To extend the existing literature, this study seeks to replicate similar efforts for Nigeria and Ghana.

\subsection{Hypotheses Tested}

Considering the above, the precise hypotheses tested in this study are as follows:

Hypothesis 1 (H1). There is no finance resource curse in Nigeria and Ghana.

The answer to this hypothesis has several implications for these two countries. Firstly, by gaining a better understanding of the link between financial access and natural resources, both Nigeria and Ghana can better reposition and manage natural resources effectively, and secondly, the information on these relations can provide policymakers with strategies to expand the exploration of their resources through access to financing both locally and internationally.

Hypothesis 2 (H2). Social investment is associated with natural resource endowments.

Social investment and natural resources are vital intuition to determine whether resource-rich countries can foster human development. Similarly, the sustainable finance paradigm also favours the need for social investment. Social investment, which covers education, health, and improved well-being, is summarised in the Human Development Index (HDI). In addition, given that Nigeria and Ghana have diverse and rich natural resources, it is fair to check if human development is influenced by natural resources.

\section{Data and Methodology}

\subsection{Data}

This study examined whether the financial resources curse exists in West Africa, focusing on Nigeria and Ghana using the annual data from various sources spanning the period 1970-2019. The data are from the Central Bank of Nigeria, the Bank of Ghana, World Development Indicator (WDI), and World Penn Table. Natural resource is measured as the total rent received from resources (\% Gross Domestic Product) $[10,12]$. Sustainable finance is proxy with financial access and measured as private credit by deposit money banks to GDP (see $[8,10,12,31,79-83])$. The environment is captured with carbon $\left(\mathrm{CO}_{2}\right)$ per capita and data is sourced from WDI. Consistent with the literature [84], Human Development Index (HDI) summarises social investment related to longevity, knowledge, and improved standard of living, and data is sourced from World Penn Table.

\subsection{Methodology}

\subsubsection{Motivation}

As hinted earlier, this study is framed in VAR/VEC Granger causality tests proposed and developed by Granger [85] Several reasons motivated the choice of the Granger causality approach. First, the Granger causality test provides an avenue to treat the variable endogenously, and issues of identifying restriction can be ignored. Second, using 
the Granger causality approach, the dynamic interaction among the variables can be uncoupled to infer the causation link. Third, the Granger causality test helps determine the implication of the short- and long-run relationship among the variables that provide additional information to policymakers.

\subsubsection{Model}

Following Wang et al. [12], our model is stated as follows:

$$
\text { nat }=f(\text { finc }, X)
$$

where nat denotes natural resources' rent and finc denotes financial access, and other vectors control variable $X$ (environment and human development index). Next, the Equation (2) was respecified econometrically as:

$$
\text { nat }_{i, t}=\alpha_{0}+\alpha_{1} \text { finc }_{i, t}+\alpha_{2} \text { env }_{i, t}+\alpha_{3} h d i_{i, t}+\mu_{i, t}
$$

where $i$ denotes index of country, $\alpha_{0}$ symbolizes constant parameter, $\alpha_{1-3}$ is intercept elasticity impacts, env is environmental variable, $h d i$ is human development index, and $\mu_{i, t}$ signifies white noise.

\subsubsection{Time Series Modelling}

This section presents the Multivariate VAR model on the link between financial access and natural resources. One, it untangles the short-run and long-run dynamics, and two, it dissects, links, and interacts the dynamics using error correction term (ect).

\section{Short-Run Relationship}

Here, we begin by formally re-modelling the Equation (2) to capture the short-run dynamic among the variables:

$$
\begin{aligned}
& \Delta n a t_{i, t}=\alpha_{10}+\sum_{k=1}^{p} \alpha_{11 i k} \Delta n a t_{i, t-k}+\sum_{k=1}^{p} \alpha_{12 i k} \Delta \text { finc }_{i, t-k}+\sum_{k=1}^{p} \alpha_{13 i k} \Delta e n v_{i, t-k} \\
& +\sum_{k=1}^{p} \alpha_{14 i k} \Delta h d i_{i, t-k}+\mu_{2 i t} \\
& \Delta \text { finc }_{i, t}=\alpha_{20}+\sum_{k=1}^{p} \alpha_{21 i k} \Delta \text { finc }_{i, t-k}+\sum_{k=1}^{p} \alpha_{22 i k} \Delta n a t_{i, t-k}+\sum_{k=1}^{p} \alpha_{23 i k} \Delta e n v_{i, t-k} \\
& +\sum_{k=1}^{p} \alpha_{24 i k} \Delta h d i_{i, t-k}+\mu_{2 i t} \\
& \Delta e n v_{i, t}=\alpha_{30}+\sum_{k=1}^{p} \alpha_{31 i k} \Delta e n v_{i, t-k}+\sum_{k=1}^{p} \alpha_{32 i k} \Delta n a t_{i, t-k}+\sum_{k=1}^{p} \alpha_{33 i k} \Delta \text { finc }_{i, t-k} \\
& +\sum_{k=1}^{p} \alpha_{34 i k} \Delta h d i_{i, t-k}+\mu_{3 i t} \\
& \Delta h d i_{i, t}=\alpha_{40}+\sum_{k=1}^{p} \alpha_{41 i k} \Delta h d i_{i, t-k}+\sum_{k=1}^{p} \alpha_{42 i k} \Delta n a t_{i, t-k}+\sum_{k=1}^{p} \alpha_{42 i k} \Delta \text { finc }_{i, t-k} \\
& +\sum_{k=1}^{p} \alpha_{44 i k} \Delta e n v_{i, t-k}+\mu_{4 i t}
\end{aligned}
$$

In Equations (3)-(6), $\alpha_{10}, \alpha_{20}, \alpha_{30}$, and $\alpha_{40}$, are taken as constants associated with an individual model for each variable, $\alpha_{11-14}, \alpha_{21-24}, \alpha_{31-34}$, and $\alpha_{41-44}$ are parameters and elasticity for each model associated with endogenous factors, $p$ is the lag length, and it is selected using the Akaike [86-88] information criterion (AIC), Schwarz's [89] Bayesian information criterion (SBIC), and Hannan and Quinn criterion [90] (HQIC) criteria, $\mu_{1 i t}, \mu_{2 i t}, \mu_{3 i t}$, and $\mu_{4 i t}$ are the shocks arising from each transmission between the variables, and $\Delta$ is the difference operator. 


\section{Long-Run Relationship}

Here, we capture the dynamics of the long-run relationship, the Equations (3)-(6) are respecified by adding the error correction term (ect) to each model and are stated algebraically as follows:

$$
\begin{aligned}
& \Delta n a t_{i, t}=\alpha_{10}+\sum_{k=1}^{p} \alpha_{11 i k} \Delta n a t_{i, t-k}+\sum_{k=1}^{p} \alpha_{12 i k} \Delta \text { finc }_{i, t-k}+\sum_{k=1}^{p} \alpha_{13 i k} \Delta e n v_{i, t-k} \\
& +\sum_{k=1}^{p} \alpha_{14 i k} \Delta h d i_{i, t-k}+\mu_{1 i t}+\lambda_{1} e c t_{1 t-1} \\
& \Delta \text { finc }_{i, t}=\alpha_{20}+\sum_{k=1}^{p} \alpha_{21 i k} \Delta \text { finc }_{i, t-k}+\sum_{k=1}^{p} \alpha_{22 i k} \Delta n a t_{i, t-k}+\sum_{k=1}^{p} \alpha_{23 i k} \Delta e n v_{i, t-k} \\
& +\sum_{k=1}^{p} \alpha_{24 i k} \Delta h d i_{i, t-k}+\mu_{2 i t}+\lambda_{2} e c t_{1 t-1} \\
& \Delta e n v_{i, t}=\alpha_{30}+\sum_{k=1}^{p} \alpha_{31 i k} \Delta e n v_{i, t-k}+\sum_{k=1}^{p} \alpha_{32 i k} \Delta n a t_{i, t-k}+\sum_{k=1}^{p} \alpha_{33 i k} \Delta \text { finc }_{i, t-k} \\
& +\sum_{k=1}^{p} \alpha_{34 i k} \Delta h d i_{i, t-k}+\mu_{3 i t}+\lambda_{3} e c t_{1 t-1} \\
& \Delta h d i_{i, t}=\alpha_{40}+\sum_{k=1}^{p} \alpha_{41 i k} \Delta h d i_{i, t-k}+\sum_{k=1}^{p} \alpha_{42 i k} \Delta n a t_{i, t-k}+\sum_{k=1}^{p} \alpha_{43 i k} \Delta f i n c_{i, t-k} \\
& +\sum_{k=1}^{p} \alpha_{44 i k} \Delta e n v_{i, t-k}+\mu_{4 i t}+\lambda_{4} e c t_{1 t-1}
\end{aligned}
$$

In Equations (7) and (10), $\lambda_{1}, \lambda_{2}, \lambda_{3}$, and $\lambda_{4}$ are the short-run coefficients to be estimated; $\mu$, is the error term, $p$ is the optimal lag length reduced by $1, \lambda$ is the speed of adjustment parameter with a negative sign, and $e c t_{t-1}$ is the error correction term, which is the lagged value of the residuals obtained from the cointegration regressions of the dependent variable on the regressors. Thus, the past disequilibrium term (i.e., ect) determines if the long-run causality holds.

\section{Results}

The empirical analysis follows the mainstream time series strategy to check the stationary properties, determine the optimal lag lengths, establish the potential cointegration in between series, and conduct the VAR/VEC Granger causality test to untangle the long-run and short-run dynamics between the variables.

\subsection{Summary Statistics}

Table 1 displays the statistical properties of the variables indicating the means and standard deviation (SD).

Table 1. Summary statistics.

\begin{tabular}{cccccc}
\hline \multirow{2}{*}{ Variables } & \multicolumn{2}{c}{ Nigeria } & \multicolumn{2}{c}{ Ghana } & \multirow{2}{*}{ Observation } \\
\cline { 2 - 5 } & Mean & SD & Mean & SD & \\
\hline nat & 14.96 & 8.19 & 9.5 & 4.33 & 50 \\
finc & 8.9 & 3.40 & 8.74 & 4.97 & 50 \\
env & 0.63 & 0.21 & 0.32 & 0.10 & 50 \\
HDI & 1.36 & 0.23 & 1.84 & 0.37 & 50 \\
\hline
\end{tabular}

Notes. Natural resource rent (nat), sustainable financing (finc), environment (env), human development index (HDI).

The average and corresponding standard deviation of natural resources for Nigeria is $14.9 \%(8.19 \%)$, while that of Ghana is $9.5 \%(4.3 \%)$. Similarly, the mean and standard deviation for Nigeria's financial access is $8.9 \%(3.4 \%)$, while that of Ghana's financial access stood at $8.7 \%(4.9 \%)$, respectively. 


\subsection{Testing for Stationarity}

In this study, the Philip and Perron (PP) [91] unit root approach is implemented. The PP unit root test offers a moderate and detailed stationary theory and is unique because it incorporates an automatic correction of autocorrelation between residuals. The PP unit root test is similar to a regression method and algebraically stated as follows:

$$
\Delta n a t=\phi n a t_{t-1}+\delta+\psi t+\sum_{i=1}^{p} \varphi \Delta n a t_{t-1}+v_{t}
$$

where $\delta$ denotes the intercept, and $\psi t$ represents time trend, which can be ignored or accounted for depending on the necessity. The results of the PP unit root tests for the variables are shown in Table 2.

Table 2. Philip and Perron (PP) unit roots test.

\begin{tabular}{ccccc}
\hline \multirow{2}{*}{ Variable } & \multicolumn{2}{c}{ Nigeria } & \multicolumn{2}{c}{ Ghana } \\
\cline { 2 - 5 } & $\mathbf{I}(\mathbf{0})$ & $\mathbf{I}(\mathbf{1})$ & $\mathbf{I}(\mathbf{0})$ & $\mathbf{I}(\mathbf{1})$ \\
\hline nat & -2.05 & $-3.74^{* *}$ & -1.82 & $-8.07^{* *}$ \\
finc & -2.13 & $-7.86^{* *}$ & -1.77 & $-10.15^{* *}$ \\
envv & -0.25 & $-7.35^{* *}$ & -0.19 & $-9.44^{* *}$ \\
HDI & -1.91 & $-5.1^{* *}$ & -0.89 & $-6.51^{* *}$ \\
\hline
\end{tabular}

Notes. Natural resource rent (nat), sustainable financing (finc). ${ }^{* *}$ denote at $5 \%$ significance levels.

The results suggest that the series were not stationary when level. To circumvent the problem, the variables were transformed to ensure stationarity, and the results are consistent with emerging literature $[81,92,93]$. Contemporary econometric literature suggests two methods for transforming a series that exhibit random walk with drift and trend stationarity properties [92,93], discussed as follows. For a random walk with drift, the model is stated as:

$$
\begin{gathered}
\Delta \text { nat }=\delta+\phi \text { nat }_{t-1}+e_{t}^{\text {nat }}, e_{t}^{\text {nat }} \sim N\left(0, \sigma_{\text {nat }}^{2}\right) \text { case } 1 \\
\Delta \text { nat }=\delta+\phi t+e_{t}^{\text {nat }}, e_{t}^{\text {nat }} \sim N\left(0, \sigma_{\text {nat }}^{2}\right) \text { case } 2 \\
H_{0}: \phi=0, \phi<0 \\
H_{0}: \delta=0, \phi<0 \\
H_{0}: \delta \neq 0, \text { and } \phi \neq 0
\end{gathered}
$$

The two cases need different treatments to induce stationarity in the variables. The first case is stochastic non-stationarity treatment, whereas the second case is known as deterministic stationarity and detrending is applied. The series becomes stationary after transformation.

\subsection{VAR Optimal Lag Selection}

The next step is to choose an optimal lag period only immediately after the series has been induced to be stationary at their first difference. In this study, the number of lag length was determined by Akaike [86-88] information criterion (AIC), Schwarz's [89] Bayesian information criterion (SBIC), and Hannan and Quinn criterion (HQIC) [90,94-96]. The criteria for choosing lag are algebraically defined as:

$$
\begin{gathered}
A I C=\ln \left|\sum_{i=0}^{\curlywedge}\right|+\frac{2 k^{\prime}}{T} \\
S B I C=\ln \left|\sum_{i=0}^{\curlywedge}\right|+\frac{k^{\prime}}{T} \ln (T) \\
H Q I C=\ln \left|\sum_{i=0}^{\curlywedge}\right|+\frac{2 k^{\prime}}{T} \ln (\ln T)
\end{gathered}
$$


where $\left|\sum_{i=0}^{\curlywedge}\right|$ is the variance-covariance matrix of the residual, $T$ is taken as the number of observations, and $k$ represents a number of regressors in all equations [96]. Tables 3 and 4 summarise the results of the optimal lag selection procedure.

Table 3. Lag order selection criteria (Nigeria).

\begin{tabular}{ccccccc}
\hline Lag & LogL & LR & FPE & & SC & HQ \\
\hline 0 & -166.8485 & NA & 0.019776 & 7.428194 & 7.587206 & 7.487761 \\
\hline 1 & 102.1234 & 479.4716 & $3.32 \times 10^{-7}$ & -3.570583 & $-2.775521 *$ & -3.272748 \\
\hline 2 & 132.2036 & $48.38991^{*}$ & $1.83 \times 10^{-7 *}$ & $-4.182766^{*}$ & -2.751655 & $-3.646663 *$
\end{tabular}

Note. ${ }^{*}$ indicates the lag length selection based on AIC: Akaike information criterion, SC: Schwarz information criterion, HQ: Hannan-Quinn information criterion, LR: sequentially modified LR test statistic (each test at $5 \%$ level), FPE: Final prediction error.

Table 4. Lag order selection criteria (Ghana).

\begin{tabular}{ccccccc}
\hline Lag & LogL & LR & FPE & AIC & SC & HQ \\
\hline 0 & -274.1889 & NA & 2.103685 & 12.09517 & 12.25418 & 12.15474 \\
\hline 1 & -55.54414 & 389.7581 & 0.000315 & 3.284528 & 4.079589 & 3.582363 \\
\hline 2 & -9.435637 & $74.17455^{*}$ & $8.65 \times 10^{-5 *}$ & $1.975462 *$ & $3.406573 *$ & $2.511565^{*}$
\end{tabular}

Note. ${ }^{*}$ indicates the lag length selection based on AIC: Akaike information criterion, SC: Schwarz information criterion, HQ: Hannan-Quinn information criterion, LR: sequentially modified LR test statistic (each test at $5 \%$ level), FPE: Final prediction error.

Almost all of the criteria accepted that lag 2 is an optimal lag period that satisfies the probability (LR) measure. This is consistent with the literature since LR is considered true under the assumption that each equation's errors are independently and identically distributed (iid) (i.e., normal distribution).

\subsection{Testing for Cointegration}

This section presents the results of the series' cointegration tests. Two series can be inferred cointegrated if they have the same stochastic trends. To explore the cointegration of variables in time series, several approaches are included [97-99]. The option cointegration test is problematic as there is no agreement among them. One cointegration test is sometimes rejected, whereas the other is not. To circumvent differing conclusions, Bayer and Hanck (B-H) [33] suggest an approach that aims to combine the different cointegration methods and provide a robust statistical intuition for testing cointegration among variables. Two reasons motivated the choice of the B-H cointegration test. One, the B-H cointegration test combines information of individual cointegration tests and accounts for multiple testing. Two, the approach is robust to sample behaviour and it modifies critical values based on Bootstrap techniques. The approach is algebraically stated as follows:

$$
\begin{gathered}
E G-J O H=-2\left[\ln \left(P_{E G}\right)+\ln \left(P_{J O H}\right)\right] \\
E G-J O H-B O-B D M=-2\left[\ln \left(P_{E G}\right)+\ln \left(P_{J O H}\right)+\ln \left(P_{B O}\right)+\ln \left(P_{B D M}\right)\right]
\end{gathered}
$$

where $E G$ signifies Engle and Granger [97], JOH signifies Johansen [100], and BO signifies Boswijk [101] and Banerjee et al. [102]. The B-H cointegration is built on the premise that series are in the same order of integration. Similarly, the B-H criteria is similar to Fisher's [103] Chi-squared test. This implies that, if Fisher's test statistic is greater than the critical value provided by B-H cointegration statistics, the hypothesis of non-convergence is rejected. Table 5 summarises the results of the B-H cointegration tests implemented. 
Table 5. Bayer and Hanck combined cointegration test.

\begin{tabular}{|c|c|c|c|}
\hline \multicolumn{4}{|c|}{ Nigeria } \\
\hline Fitted Model & EG-JOH & EG-JOH-BO-BDM & Cointegration Remarks \\
\hline nat $=\mathrm{f}($ finc $)$ & $45.20^{* * *}$ & $67.78^{* * *}$ & Yes \\
\hline nat $=\mathrm{f}($ finc, env $)$ & $45.95^{* * *}$ & $74.3^{* * *}$ & Yes \\
\hline nat $=\mathrm{f}($ finc, env, HDI $)$ & $47.40 * * *$ & $86.2^{* * *}$ & Yes \\
\hline \multicolumn{4}{|c|}{ Ghana } \\
\hline Fitted Model & EG-JOH & EG-JOH-BO-BDM & Cointegration Remarks \\
\hline nat $=\mathrm{f}$ (finc) & $61.25 * * *$ & $88.46^{* * *}$ & Yes \\
\hline nat $=\mathrm{f}($ finc, env $)$ & $63.51 * * *$ & $101.7^{* * *}$ & Yes \\
\hline nat $=f($ finc,, env, HDI $)$ & $71.20 * * *$ & $114.18^{* * *}$ & Yes \\
\hline $1 \%$ critical values & 15.70 & 29.8 & \\
\hline $5 \%$ critical values & 10.4 & 19.8 & \\
\hline
\end{tabular}

Note. Natural resource rent (nat), sustainable financing (finc), environment (env), human development index (HDI); EG signifies Engle and Granger [97], JOH signifies Johansen [100], and BO signifies Boswijk [101] and Banerjee et al. [102]. ${ }^{* * *}$, denote $1 \%$, significance levels.

The results of the B-H cointegration confirmed the existence of cointegration among the variables. This suggests that the variables have the ability to converge back to their longterm mean. Therefore, we proceed to implement the VAR/VEC Granger causality tests.

\subsection{VAR/VEC Granger Causality Tests}

As hinted earlier, this study is framed in Granger causality tests and the methodology is based on two key assumptions: One, the series must be stationary, and two, there must be evidence of cointegration among the series [104-108]. However, since these assumptions have been met in the preceding section, we have applied the VAR/VEC Granger causality tests and the results are summarised in Table 6.

Table 6. Vector Autoregressive/Vector Error Correction Granger causality tests.

\begin{tabular}{|c|c|c|c|c|c|}
\hline \multicolumn{6}{|c|}{ Nigeria } \\
\hline \multirow{2}{*}{$\begin{array}{l}\text { Independent } \\
\text { Variable }\end{array}$} & \multicolumn{4}{|c|}{ Dependent Variable } & \multirow{2}{*}{$\begin{array}{c}\text { Long- } \\
\text { Runect }_{t-1}\end{array}$} \\
\hline & nat $_{t}$ & finc $_{t}$ & env $_{t}$ & $\mathrm{HDI}_{\mathrm{t}}$ & \\
\hline nat $_{t-k}$ & - & $\begin{array}{l}5.91 * * \\
{[0.04]}\end{array}$ & $\begin{array}{c}10.77^{* *} \\
{[0.01]}\end{array}$ & $\begin{array}{c}0.72 \\
{[0.69]}\end{array}$ & $\begin{array}{c}-0.27^{* *} \\
(0.13)\end{array}$ \\
\hline finc $_{t-k}$ & $\begin{array}{c}11.72 * * \\
{[0.00]}\end{array}$ & - & $\begin{array}{c}7.52 * * \\
{[0.00]}\end{array}$ & $\begin{array}{c}0.96 \\
{[0.61]}\end{array}$ & $\begin{array}{c}-0.0006^{* *} \\
(0.00)\end{array}$ \\
\hline $\operatorname{env}_{t-k}$ & $\begin{array}{l}5.45^{* *} \\
{[0.04]}\end{array}$ & $\begin{array}{c}18.13^{* * *} \\
{[0.00]}\end{array}$ & - & $\begin{array}{l}7.44^{* *} \\
{[0.00]}\end{array}$ & $\begin{array}{l}0.11^{* *} \\
(0.01)\end{array}$ \\
\hline $\mathrm{HDI}_{\mathrm{t}-\mathrm{k}}$ & $\begin{array}{l}2.26 \\
{[0.31]}\end{array}$ & $\begin{array}{c}14.07^{* * *} \\
{[0.00]}\end{array}$ & $\begin{array}{c}3.09 \\
{[0.21]}\end{array}$ & - & $\begin{array}{c}-0.0006^{* *} \\
(0.00)\end{array}$ \\
\hline \multicolumn{6}{|c|}{ Ghana } \\
\hline \multirow{2}{*}{$\begin{array}{l}\text { Independent } \\
\text { Variable }\end{array}$} & \multicolumn{4}{|c|}{ Dependent Variable } & \multirow{2}{*}{$\begin{array}{c}\text { Long- } \\
\text { Runect }_{t-1}\end{array}$} \\
\hline & nat $_{t}$ & finc $_{t}$ & $e v_{t}$ & $\mathrm{HDI}_{\mathrm{t}}$ & \\
\hline nat $_{t-k}$ & - & $\begin{array}{c}2.65 \\
{[0.26]}\end{array}$ & $\begin{array}{l}7.19 * * \\
{[0.02]}\end{array}$ & $\begin{array}{l}4.89 * * \\
{[0.03]}\end{array}$ & $\begin{array}{c}-0.0025^{* *} \\
(0.00)\end{array}$ \\
\hline finc $_{t-k}$ & $\begin{array}{c}8.66^{* * *} \\
{[0.00]}\end{array}$ & - & $\begin{array}{l}8.56 * * \\
{[0.01]}\end{array}$ & - & $\begin{array}{c}-0.0001 \\
(0.00)\end{array}$ \\
\hline $\operatorname{env}_{t-k}$ & $\begin{array}{l}3.98 * * \\
{[0.00]}\end{array}$ & $\begin{array}{c}2.44 \\
{[0.29]}\end{array}$ & - & $\begin{array}{c}0.27 \\
{[0.89]}\end{array}$ & $\begin{array}{c}-0.00008 * \\
(0.00)\end{array}$ \\
\hline $\mathrm{HDI}_{\mathrm{t}-\mathrm{k}}$ & $5.05^{* *}$ & $\begin{array}{c}12.20 * * * \\
{[0.00]}\end{array}$ & $\begin{array}{c}6.17 * * \\
{[0.04]}\end{array}$ & - & $\begin{array}{c}0.005^{* * *} \\
(0.00)\end{array}$ \\
\hline
\end{tabular}

Note. Natural resource rent (nat), sustainable financing (finc), environment (env), human development index $(\mathrm{HDI}) ;()$ is the standard error; [ ], is probability value ${ }^{* * *}, * *, *$ denote $1 \%, 5 \%, 10 \%$ significance levels.

The findings of the VAR/VEC Granger causality can be summarised as follows: (a) There is the existence of cointegration among the variables in both countries (Nigeria and Ghana), (b) financial access unidirectionally Granger cause natural resources in Ghana, indicating that financial access has a strong endogenous influence on natural resources. 
In contrast, financial access bidirectionally Granger causes natural resources in Nigeria, indicating a feedback effect between the variables. (c) The speed of convergence of the variable to their long-term mean was negative and statistically significant. However, the $e c t_{t-1}$ for Nigeria is higher as compared to that of Ghana. (d) The medium through which sustainable finance affects natural resource curse has been identified as the human development index (economic welfare) in Ghana. (e) As for the result of other covariates, there was bidirectional Granger causality between environment, human development index, and natural resources in Ghana. In contrast, bidirectionally Granger causality was observed between environment and natural resources for Nigeria.

Table 7 displays the statistical output for the stability test using the Chow forecasting tests. The results show that variables are stable within the period examined.

Table 7. Statistical output for stability test (Chow forecast test).

\begin{tabular}{ccccc}
\hline Forecast Period & F-Statistics & $\begin{array}{c}p \text {-Value of } \\
\text { F-Statistics }\end{array}$ & $\begin{array}{c}\text { Log-Likelihood } \\
\text { ratio }\end{array}$ & $\begin{array}{c}p \text {-Value of Log of } \\
\text { Likelihood }\end{array}$ \\
\hline $1985-2015$ & 78.22 & 0.601 & 121.93 & 0.201 \\
\hline
\end{tabular}

\subsection{Discussion of Findings}

The study aimed to establish whether a financing resource curse hypothesis exists in Nigeria and Ghana. The methodological contribution is based on three statistical premises. First, the study evaluated the stationarity properties of the series using the PP unit root tests and Chow test for checking the stability properties. Second, the Bayer and Hanck [33] combined cointegration approach was used to check the variables' potential convergence. Third, the study applied the VAR/VEC Granger causality tests, which help to untangle the short- and long-run dynamics among the variables. The findings confirmed the existence of cointegration among the variables. Similarly, financial access unidirectionally Granger causes natural resources in Ghana, whereas bidirectional Granger causality was observed for Nigeria.

The results have many consequences for the efficient and successful natural resources management of the two countries. For Ghana, the is strong evidence to suggest that financial access will help promote natural resource utilisation, whereas the case of Nigeria is somewhat different as evidence shows that the present financial access cannot reassure natural resources management. Based on the findings, the following suggestions are crucial for both countries: (a) The repositioning of the financial sector for sustainable development is urgently important for the successful and productive management of natural resources for growth, and (b) there is a need for the financial sector in the two countries to perform as an intermediary by mobilising funds aimed at promoting domestic exploration of natural resources, which will upturn the financing resource curse to a blessing.

In answering the hypothesis 1: Evidence from the results has clearly shown the existence of a financial resources curse in the two West African countries (Nigeria and Ghana) examined. With regards to the hypothesis 2, strong evidence emerged, indicating a strong relationship between human development and natural resources endowments in Ghana. However, the Granger causality between human development and natural resources for Nigeria turned out to be statistically insignificant. Additionally, the findings of this study are consistent with Wang et al. [12], but contrary to the negative relationships between financial access and natural resources found by Bhattacharyya and Holder [70].

\section{Conclusions and Policy Implications}

For the past 50 years, the resource curse hypothesis has continued to trend in empirical research, yet the evidence is far from sufficient to make a conclusion. A major reason for the lack of consensus is that natural resources are associated with many factors. However, these studies are ignoring the possibility that financial access can have a greater effect on the effective management of natural resource endowments. Using the Bayer and Hanck [33] combined cointegration test and Granger causality approach, the study examined whether 
sustainable financing can help natural resource management in Nigeria and Ghana. Our results showed that financial access unidirectionally Granger causes natural resources in Ghana, whereas bidirectional Granger causality was observed in Nigeria. Similarly, there was cointegration among the variables, but the speed of convergence was relatively higher in Nigeria than that of Ghana. Additionally, the medium through which sustainable finance affects natural resource curse has been identified as human development (economic welfare).

Thus, the study recommends that financial access can help both countries manage their resources effectively, which may spur economic recovery and promote socioeconomic development. This can be accomplished by offering loans targeted for exploration, discovery, and development to private investors. Sustainable finance would help attract foreign investors, mobilise funds for sustainable growth, and promote the formation of a strong financial institution. Furthermore, appropriate sustainable finance, through equitable social financing, will raise living standards and guarantee sustainability. Future studies will channel the efforts towards the sectorial effect of financial development, which may complement the findings of the present study.

Author Contributions: Conceptualization, O.A.S., methodology, O.A.S., validation, O.A.S., formal investigation, O.A.S.; resources, O.A.S. and J.O.E.; data curation, O.A.S.; writing, O.A.S.; original draft preparation, O.A.S. and J.O.E.; visualization, J.O.E.; supervision, O.A.S.; project administration, O.A.S. and J.O.E.; funding acquisition, O.A.S. and J.O.E. All authors have read and agreed to the published version of the manuscript.

Funding: The research received no external funding.

Institutional Review Board Statement: Ethical review and approval was not required for the study as the research does not involve humans.

Informed Consent Statement: Not applicable.

Data Availability Statement: Data available on request.

Conflicts of Interest: The authors declare no conflict of interest.

\section{References}

1. Jeanne, O.; Korinek, A. Excessive volatility in capital flows: A Pigouvian taxation approach. Am. Econ. Rev. 2010, 100, 403-407. [CrossRef]

2. Van der Ploeg, F. Natural resources: Curse or blessing? J. Econ. Lit. 2011, 49, 366-420. [CrossRef]

3. Brunnschweiler, C.N. Cursing the blessings? Natural resource abundance, institutions, and economic growth. World Dev. 2008, 36, 399-419. [CrossRef]

4. Durusu-Ciftci, D.; Ispir, M.S.; Yetkiner, H. Financial development and economic growth: Some theory and more evidence. J. Policy Model. 2017, 39, 290-306. [CrossRef]

5. Sadik-Zada, E.R. Distributional Bargaining and the Speed of Structural Change in the Petroleum Exporting Labor Surplus Economies. Eur. J. Dev. Res. 2020, 32, 51-98. [CrossRef]

6. Botev, J.; Égert, B.; Jawadi, F. The nonlinear relationship between economic growth and financial development: Evidence from developing, emerging and advanced economies. Int. Econ. 2019, 160, 3-13. [CrossRef]

7. Bucci, A.; Marsiglio, S. Financial development and economic growth: Long-run equilibrium and transitional dynamics. Scott. J. Political Econ. 2019, 66, 331-359. [CrossRef]

8. Redmond, T.; Nasir, M.A. Role of natural resource abundance, international trade and financial development in the economic development of selected countries. Resour. Policy 2020, 66, 101591. [CrossRef]

9. Asiedu, E.; Lien, D. Democracy, foreign direct investment and natural resources. J. Int. Econ. 2011, 84, 99-111. [CrossRef]

10. Shahbaz, M.; Naeem, M.; Ahad, M.; Tahir, I. Is natural resource abundance a stimulus for financial development in the USA? Resour. Policy 2018, 55, 223-232. [CrossRef]

11. Asongu, S.A. Comparative sustainable development in sub-Saharan Africa. Sustain. Dev. 2018, 26, 638-651. [CrossRef]

12. Wang, L.; Chang, H.L.; Sari, A.; Sowah, J.K., Jr.; Cai, X.Y. Resources or development first: An interesting question for a developing country. Resour. Policy 2020, 68, 101714. [CrossRef]

13. Di John, J. Is There Really a Resource Curse? A Critical Survey of Theory and Evidence. Glob. Gov. 2011, 17, 167-184. [CrossRef]

14. Dwumfour, R.A.; Ntow-Gyamfi, M. Natural resources, financial development and institutional quality in Africa: Is there a resource curse? Resour. Policy 2018, 59, 411-426. [CrossRef] 
15. Zhang, Q.; Brouwer, R. Is China Affected by the Resource Curse? A Critical Review of the Chinese Literature. J. Policy Model. 2020, 42, 133-152. [CrossRef]

16. Benigno, G.; Fornaro, L. The Financial Resource Curse. Scand. J. Econ. 2014, 116, 58-86. [CrossRef]

17. Adetutu, M.O.; Odusanya, K.A.; Ebireri, J.E.; Murinde, V. Oil booms, bank productivity and natural resource curse in finance. Econ. Lett. 2020, 186, 108517. [CrossRef]

18. Fijorek, K.; Jurkowska, A.; Jonek-Kowalska, I. Financial contagion between the financial and the mining industries-Empirical evidence based on the symmetric and asymmetric CoVaR approach. Resour. Policy 2021, 70, 101965. [CrossRef]

19. Olayungbo, D. Effects of oil export revenue on economic growth in Nigeria: A time varying analysis of resource curse. Resour. Policy 2019, 64, 101469. [CrossRef]

20. Porter, D.; Watts, M. Righting the Resource Curse: Institutional Politics and State Capabilities in Edo State, Nigeria. J. Dev. Stud. 2017, 53, 249-263. [CrossRef]

21. Okpanachi, E.; Andrews, N. Preventing the oil "resource curse" in Ghana: Lessons from Nigeria. World Futures 2012, 68, 430-450. [CrossRef]

22. Sala-I-Martin, X.; Subramanian, A. Addressing the Natural Resource Curse: An Illustration from Nigeria. J. Afr. Econ. 2013, 22, 570-615. [CrossRef]

23. Li, Y.; Naqvi, B.; Caglar, E.; Chu, C.-C. N-11 countries: Are the new victims of resource-curse? Resour. Policy 2020, 67, 101697. [CrossRef]

24. Kumah-Abiwu, F. Democratic Institutions, Natural Resource Governance, and Ghana's Oil Wealth. Soc. Sci. 2017, 6, 21. [CrossRef]

25. Andrews, N.; Siakwah, P. Oil and Development in Ghana: Beyond the Resource Curse; Routledge: Abingdon, UK, 2020.

26. Ofosu-Mensah, E.A. Historical and Modern Artisanal Small-Scale Mining in Akyem Abuakwa, Ghana. Afr. Today 2017, 64, 69. [CrossRef]

27. Kopiński, D.; Polus, A.; Tycholiz, W. Resource curse or resource disease? Oil in Ghana. Afr. Aff. 2013, 112, 583-601. [CrossRef]

28. Shobande, O.A. Effect of Economic Integration on Agricultural Export Performance in Selected West African Countries. Economies 2019, 7, 79. [CrossRef]

29. Joseph, E.; Shobande, O.A. Revalidating Saving-Investment Comovement in Nigeria: Surprises, Stylized Facts and Explanations. Theor. Econ. Lett. 2018, 8, 3594-3610. [CrossRef]

30. Zaidi, S.A.H.; Wei, Z.; Gedikli, A.; Zafar, M.W.; Hou, F.; Iftikhar, Y. The impact of globalization, natural resources abundance, and human capital on financial development: Evidence from thirty-one OECD countries. Resour. Policy 2019, 64, 101476. [CrossRef]

31. Asif, M.; Khan, K.B.; Anser, M.K.; Nassani, A.A.; Abro, M.M.Q.; Zaman, K. Dynamic interaction between financial development and natural resources: Evaluating the "Resource curse" hypothesis. Resour. Policy 2020, 65, 101566. [CrossRef]

32. Khan, Z.; Hussain, M.; Shahbaz, M.; Yang, S.; Jiao, Z. Natural resource abundance, technological innovation, and human capital nexus with financial development: A case study of China. Resour. Policy 2020, 65, 101585. [CrossRef]

33. Bayer, C.; Hanck, C. Combining non-cointegration tests. J. Time Ser. Anal. 2013, 34, 83-95. [CrossRef]

34. Weber, O.; Banks, Y. Corporate sustainability assessment in financing the extractive sector. J. Sustain. Financ. Invest. 2012, 2, 64-81.

35. Schoenmaker, D.; Schramade, W. Principles of Sustainable Finance; Oxford University Press: Oxford, UK, 2018.

36. Nabeeh, N.A.; Abdel-Basset, M.; Soliman, G. A model for evaluating green credit rating and its impact on sustainability performance. J. Clean. Prod. 2021, 280, 124299. [CrossRef] [PubMed]

37. Fatemi, A.M.; Fooladi, I.J. Sustainable finance: A new paradigm. Glob. Finance J. 2013, 24, 101-113. [CrossRef]

38. Jeucken, M. Sustainable Finance and Banking: The Financial Sector and the Future of the Planet; Earthscan: London, UK, 2010.

39. Canto-Cuevas, F.-J.; Palacín-Sánchez, M.-J.; Di Pietro, F. Trade credit as a sustainable resource during an SME's life cycle. Sustainability 2019, 11, 670. [CrossRef]

40. Quatrini, S. Challenges and opportunities to scale up sustainable finance after the COVID-19 crisis: Lessons and promising innovations from science and practice. Ecosyst. Serv. 2021, 101240, 101240. [CrossRef]

41. Sharma, G.D.; Talan, G.; Bansal, S.; Jain, M. Is there a cost for sustainable investments: Evidence from dynamic conditional correlation. J. Sustain. Financ. Invest. 2021, 1-21. [CrossRef]

42. Migliorelli, M. What Do We Mean by Sustainable Finance? Assessing Existing Frameworks and Policy Risks. Sustainability 2021, 13, 975. [CrossRef]

43. Nguyen, T.H.; Elmagrhi, M.H.; Ntim, C.G.; Wu, Y. Environmental performance, sustainability, governance and financial performance: Evidence from heavily polluting industries in China. Bus. Strat. Environ. 2021. [CrossRef]

44. Shobande, O.A. The effects of energy use on infant mortality rates in Africa. Environ. Sustain. Indic. 2020, 5, 100015. [CrossRef]

45. Shobande, O.A. Effects of Energy Use on Socioeconomic Predictors in Africa: Synthesizing Evidence. Studia Univ. Vasile Goldiş Arad Seria Ştiinţe Econ. 2019, 29, 21-40. [CrossRef]

46. Ziolo, M.; Bak, I.; Cheba, K. The role of sustainable finance in achieving sustainable development goals: Does it work? Technol. Econ. Dev. Econ. 2020, 27, 45-70. [CrossRef]

47. Yoshino, N.; Taghizadeh-Hesary, F.; Otsuka, M. Covid-19 and Optimal Portfolio Selection for Investment in Sustainable Development Goals. Finance Res. Lett. 2021, 38, 101695. [CrossRef]

48. Bernardini, E.; Di Giampaolo, J.; Faiella, I.; Poli, R. The impact of carbon risk on stock returns: Evidence from the European electric utilities. J. Sustain. Financ. Invest. 2021, 11, 1-26. [CrossRef] 
49. Akomea-Frimpong, I.; Adeabah, D.; Ofosu, D.; Tenakwah, E.J. A review of studies on green finance of banks, research gaps and future directions. J. Sustain. Financ. Invest. 2021, 1-24. [CrossRef]

50. Piñeiro-Chousa, J.; López-Cabarcos, M.Á.; Caby, J.; Šević, A. The influence of investor sentiment on the green bond market. Technol. Forecast. Soc. Chang. 2021, 162, 120351. [CrossRef]

51. Okonjo, J. International Financial Regulation and Sustainable Finance. In Encyclopedia of Law and Development; Edward Elgar Publishing: Cheltenham, UK, 2021.

52. Hegeman, P.D.; Sørheim, R. Why do they do it? Corporate venture capital investments in cleantech start-ups. J. Clean. Prod. 2021, 294, 126315. [CrossRef]

53. Shobande, O.A.; Shodipe, O.T. Monetary Policy Interdependency in Fisher Effect: A Comparative Evidence. J. Cent. Bank. Theory Pract. 2021, 10, 203-226. [CrossRef]

54. Weber, O. Environmental Credit Risk Management in Banks and Financial Service Institutions. Bus. Strat. Environ. 2012, 21, 248-263. [CrossRef]

55. Sanchez-Roger, M.; Oliver-Alfonso, M.D.; Sanchís-Pedregosa, C. Bail-in a sustainable mechanism for rescuing banks. Sustainability 2018, 10, 3789. [CrossRef]

56. Anagnostopoulos, T.; Skouloudis, A.; Khan, N.; Evangelinos, K. Incorporating Sustainability Considerations into Lending Decisions and the Management of Bad Loans: Evidence from Greece. Sustainability 2018, 10, 4728. [CrossRef]

57. Escrig-Olmedo, E.; Fernández-Izquierdo, M.Á.; Ferrero-Ferrero, I.; Rivera-Lirio, J.M.; Muñoz-Torres, M.J. Rating the Raters: Evaluating how ESG Rating Agencies Integrate Sustainability Principles. Sustainability 2019, 11, 915. [CrossRef]

58. Korzeb, Z.; Samaniego-Medina, R. Sustainability Performance: A Comparative Analysis in the Polish Banking Sector. Sustainability 2019, 11, 653. [CrossRef]

59. Gianfrate, G.; Lorenzato, G. Stimulating Non-Bank Financial Institutions' Participation in Green Investments; ADBI Working Paper No. 860; ADBI: Tokyo, Japan, 2018.

60. Busch, T.; Bauer, R.; Orlitzky, M. Sustainable development and financial markets: Old paths and new avenues. Bus. Soc. 2016, 55, 303-329. [CrossRef]

61. Zhu, B.; Zhai, S.; He, J. Is the Development of China's Financial Inclusion Sustainable? Evidence from a Perspective of Balance. Sustainability 2018, 10, 1200. [CrossRef]

62. Tolliver, C.; Fujii, H.; Keeley, A.R.; Managi, S. Green Innovation and Finance in Asia. Asian Econ. Policy Rev. 2021, 16, 67-87. [CrossRef]

63. Flammer, C. Corporate green bonds. J. Financ. Econ. 2021. [CrossRef]

64. Galbreath, J. ESG in Focus: The Australian Evidence. J. Bus. Ethics 2013, 118, 529-541. [CrossRef]

65. Razak, L.A.; Ibrahim, M.H.; Ng, A. Which Sustainability Dimensions Affect Credit Risk? Evidence from Corporate and CountryLevel Measures. J. Risk Financ. Manag. 2020, 13, 316. [CrossRef]

66. Capasso, G.; Gianfrate, G.; Spinelli, M. Climate Change and Credit Risk. Available online: https://www.longfinance.net/media/ documents /eri_wp_climatechange_creditrisk_2020_1.pdf (accessed on 2 February 2021).

67. Bauer, R.; Hann, D. Corporate Environmental Management and Credit Risk. SSRN Electron. J. 2010. [CrossRef]

68. Chava, S. Environmental externalities and cost of capital. Manag. Sci. 2014, 60, 2223-2247. [CrossRef]

69. Faisal, F.; Sulaiman, Y.; Tursoy, T. Does an asymmetric nexus exist between financial deepening and natural resources for emerging economy? Evidence from multiple break cointegration test. Resour. Policy 2019, 64, 101512. [CrossRef]

70. Bhattacharyya, S.; Hodler, R. Do Natural Resource Revenues Hinder Financial Development? The Role of Political Institutions. World Dev. 2014, 57, 101-113. [CrossRef]

71. Kurronen, S. Financial sector in resource-dependent economies. Emerg. Mark. Rev. 2015, 23, 208-229. [CrossRef]

72. Benigno, G.; Fornaro, L.; Wolf, M. The Global Financial Resource Curse; Staff Report No. 915; Federal Reserve Bank of New York: New York, NY, USA, 2020.

73. Canh, N.P.; Thong, N.T. Nexus between financialisation and natural resources rents: Empirical evidence in a global sample. Resour. Policy 2020, 66, 101590. [CrossRef]

74. Khan, H.U.R.; Islam, T.; Yousaf, S.U.; Zaman, K.; Shoukry, A.M.; Sharkawy, M.A.; Gani, S.; Aamir, A.; Hishan, S.S. The impact of financial development indicators on natural resource markets: Evidence from two-step GMM estimator. Resour. Policy 2019, 62, 240-255. [CrossRef]

75. Guan, J.; Kirikkaleli, D.; Bibi, A.; Zhang, W. Natural resources rent nexus with financial development in the presence of globalisation: Is the "resource curse" exist or myth? Resour. Policy 2020, 66, 101641. [CrossRef]

76. Yıldırım, S.; Gedikli, A.; Erdoğan, S.; Yıldırım, D.Ç. Natural resources rents-financial development nexus: Evidence from sixteen developing countries. Resour. Policy 2020, 68, 101705. [CrossRef]

77. Gokmenoglu, K.K.; Rustamov, B. Examining the World Bank Group lending and natural resource abundance induced financial development in KART countries. Resour. Policy 2019, 63, 101433. [CrossRef]

78. Yuxiang, K.; Chen, Z. Resource abundance and financial development: Evidence from China. Resour. Policy 2011, 36, 72-79. [CrossRef]

79. Asiedu, E.; Kalonda-Kanyama, I.; Ndikumana, L.; Nti-Addae, A. Access to Credit by Firms in Sub-Saharan Africa: How Relevant is Gender? Am. Econ. Rev. 2013, 103, 293-297. [CrossRef] 
80. Asiedu, E.; Kalonda-Kanyama, I.; Ndikumana, L.; Nti-Addae, A. Replication data for: Access to Credit by Firms in Sub-Saharan Africa: How Relevant Is Gender? American Economic Association: Nashville, TN, USA, 2019.

81. Shahbaz, M. Does financial instability increase environmental degradation? Fresh evidence from Pakistan. Econ. Model. 2013, 33, 537-544. [CrossRef]

82. Beck, T.; Poelhekke, S. Follow the Money: Does the Financial Sector Intermediate Natural Resource Windfalls? Tinbergen Institute Discussion Paper 2017-027/VIII; Tinbergen Institute: Amsterdam, The Netherlands, 2017; 48p.

83. Shobande, O.A.; Shodipe, O.T. Carbon policy for the United States, China and Nigeria: An estimated dynamic stochastic general equilibrium model. Sci. Total. Environ. 2019, 697, 134130. [CrossRef]

84. Alvarado, R.; Tillaguango, B.; López-Sánchez, M.; Ponce, P.; Işık, C. Heterogeneous impact of natural resources on income inequality: The role of the shadow economy and human capital index. Econ. Anal. Policy 2021, 69, 690-704. [CrossRef]

85. Granger, C.W.J.; Elliott, C.M. A Fresh Look at Wheat Prices and Markets in the Eighteenth Century. Econ. Hist. Rev. 1967, $20,257$. [CrossRef]

86. Akaike, H. A new look at the statistical model identification. IEEE Trans. Autom. Control. 1974, 19, 716-723. [CrossRef]

87. Akaike, H. Likelihood of a model and information criteria. J. Econ. 1981, 16, 3-14. [CrossRef]

88. Akaike, H. Prediction and Entropy. In A Celebration of Statistics; Atkinson, A.C., Fienberg, S.E., Eds.; Springer International Publishing: New York, NY, USA, 1985; pp. 387-410.

89. Schwarz, G. Estimating the Dimension of a Model. Ann. Stat. 1978, 6, 461-464. [CrossRef]

90. Hannan, E.J.; Quinn, B.G. The Determination of the Order of an Autoregression. J. R. Stat. Soc. Ser. B Stat. Methodol. 1979, 41, 190-195. [CrossRef]

91. Perron, P. The Great Crash, the Oil Price Shock, and the Unit Root Hypothesis. Econometrica 1989, 57, 1361. [CrossRef]

92. Nawaz, M.A.; Seshadri, U.; Kumar, P.; Aqdas, R.; Patwary, A.K.; Riaz, M. Nexus between green finance and climate change mitigation in N-11 and BRICS countries: Empirical estimation through difference in differences (DID) approach. Environ. Sci. Pollut. Res. 2020, 28, 6504-6519. [CrossRef]

93. Chishti, M.Z.; Ahmad, M.; Rehman, A.; Khan, M.K. Mitigations pathways towards sustainable development: Assessing the influence of fiscal and monetary policies on carbon emissions in BRICS economies. J. Clean. Prod. 2021, 292, 126035. [CrossRef]

94. Baltagi, B.H. Econometric Analysis of Data Panel; John Wiley \& Sons Ltd.: Chichester, UK, 2005.

95. Stock, J.H.; Watson, M.W. Why Has U.S. Inflation Become Harder to Forecast? J. Money, Crédit. Bank. 2007, 39, 3-33. [CrossRef]

96. Brooks, C. Introductory Econometrics for Finance; Cambridge University Press: Cambridge, UK, 2019.

97. Engle, R.F.; Granger, C.W.J. Co-Integration and Error Correction: Representation, Estimation, and Testing. Econometrica 1987, 55, 251. [CrossRef]

98. Johansen, S. Statistical analysis of cointegration vectors. J. Econ. Dyn. Control. 1988, 12, 231-254. [CrossRef]

99. Carrion-I-Silvestre, J.L.; Sansó, A. Testing the Null of Cointegration with Structural Breaks. Oxf. Bull. Econ. Stat. 2006, 68, 623-646. [CrossRef]

100. Johansen, S. Identifying restrictions of linear equations with applications to simultaneous equations and cointegration. J. Econ. 1995, 69, 111-132. [CrossRef]

101. Boswijk, H.P. Testing for an unstable root in conditional and structural error correction models. J. Econ. 1994, 63, 37-60. [CrossRef]

102. Banerjee, A.; Dolado, J.J.; Mestre, R. Error-correction Mechanism Tests for Cointegration in a Single-equation Framework. J. Time Ser. Anal. 1998, 19, 267-283. [CrossRef]

103. Fisher, R.A. Statistical Methods for Research Workers, 4th ed.; Oliver \& Boyd: Edinburgh, UK, 1932.

104. Götz, T.B.; Hecq, A.; Smeekes, S. Testing for Granger causality in large mixed-frequency VARs. J. Econ. 2016, 193, 418-432. [CrossRef]

105. Liu, H.; Song, H. New Evidence of Dynamic Links between Tourism and Economic Growth Based on Mixed-Frequency Granger Causality Tests. J. Travel Res. 2018, 57, 899-907. [CrossRef]

106. Ghysels, E.; Hill, J.B.; Motegi, K. Testing a large set of zero restrictions in regression models, with an application to mixed frequency Granger causality. J. Econ. 2020, 218, 633-654. [CrossRef]

107. Hill, J.B.; Motegi, K. A max-correlation white noise test for weakly dependent time series. Econom. Theory 2020, 36, 907-960. [CrossRef]

108. Inoue, A.; Kilian, L. The uniform validity of impulse response inference in autoregressions. J. Econom. 2020, 215, 450-472. [CrossRef] 